\title{
Free Trade or Unfettered National/Corporate Interest?
}

There is a gap between theory and practice when it comes to assessing the role of free trade in a globalised world. This is especially true in relation to the neo-classical interpretation of free trade and what it actually means in practice. We explore an analysis which advocates moderation, neither the unbridled free trade implicit in laissez faire nor autarky nor aggressive mercantilist selfpromotion of national and corporate interests. The intangible assets of intellectual property rights and their valuation within the framework of globalization is an important part of the equation and hold both positive benefits and negative implications within the US and globally. If the balance among forces is not maintained the losers are labor, government, democracy itself, the environment and consumers.

Keywords: Free Trade; Globalization; IPR; Valuation.

\section{Introduction}

It may be that the area of economics in which theory and practice are most diametrically opposed is free trade.

In theory, free trade should, must, benefit all parties involved. The grounds for this should be intuitively obvious to the most casual observer of economics. One obvious consideration is autonomy. If a trade were not beneficial to a party, that party would simply not engage in the trade.

An independent consideration stems from David Ricardo's notion of comparative advantage. If each party produces what it can produce with relative efficiency and trades for other goods and services, total production will be greater and all parties could be better off. Moreover, such trade allows for specialization, which should increase efficiency. In short, free trade is an engine of Pareto optimality, leading to economic distributions such that it is impossible to make anyone better off without making others worse off.

In practice, the side of the road to universal benefit is littered with failures. Countries that abided by the free market, free trade, Washington Consensus 
grew more slowly, or not at all. The countries that staged economic miracles, including the United States in the nineteenth and twentieth century's, all rejected free trade in favor of some measure of dirigisme, including high tariffs and government support for value-added sectors.

The winners all regarded comparative advantage not as a given constant, but as a dynamic variable, and they forged their own comparative advantages. Even the United States, influenced by Alexander Hamilton, imposed heavy tariffs, invested in banks, canals and manufacturing, refused to pay royalties on intellectual property (Cohen and DeLong, 2016). Today, it would create an uproar if royalties on Intellectual Property Rights (IPR) were not paid.

In fact, IPR and the valuation of the actual worth of intangible assets is playing a central role in the reason for the United States under President Trump initiating a trade war with higher tariffs being imposed on competitors, including allies. US IPR is highly valued by countries who do not have the expertise or funds to create their own military or business technology to operate on a competitive global basis. Smugglers, mainly from Iran, North Korea, Russia and China regularly try to steal and sell advanced American technology to hostile countries, including blueprints of patents that can be used for weapons and espionage.

In a recent example, a Texas businessman, Peter A. Zuccarelli who was working with a smuggling group headed by a Pakistani-born US citizen was paid US $\$ 1.5$ million to buy special radiation-resistant circuits for space programs in China and Russia. Documents shown in court proved that Mr. Zuccarelli had created fake shipping documents while mislabelling the circuits as parts for touch-screen computers. He was sentenced in January 2018 to four years in prison.

This tendency for IPR theft related to military technology by adversaries of the US has increased far beyond levels known during the Cold War era. (Nixon, 2018).

China has been viewed by many US policy makers as a nation practicing a dangerous innovative mercantilism that steals American IPR and trade secrets to further its quest for global economic and political dominance. China has been breaking World Trade Organisation rules since joining in 2001 by stealing IPR through any means available but mainly through cyberattack (Taplin, 2016).

Therefore, when we are assessing issues concerning free trade, IPR, and globalization it needs to be asked whether it is a question of free trade for all or one of unfettered national interest. Along similar lines, the historic and ongoing use by countries of any trade policy to their own advantage or to impose free trade policies favourable to themselves on weaker countries, combined with the 
practical failure of free trade policies, may lead us to question the underpinnings of free trade theory.

\section{Blind Spots in Free Trade Theory}

The theory, in the spirit of non-interference, laissez faire, plausibly insists that any restrictions imposed on trade must be self-defeating. In practice, all the successful countries have ignored that insistence with impunity. How could practice differ so radically from theory?

An answer may turn on a number of blind spots in the theory. If one accounts for these, then one may not be deceived by the appearance of free trade leading to Pareto optimality, much less universal benefit.

One blind spot is the assumption of autonomy. For centuries, European countries traded primarily with their colonies. That trade was highly unequal, with the European countries importing low value-added commodities and exporting relatively high value-added finished goods. The trade was often enforced by the threat of (or actual) violence, and the elite rulers of the colonies were often put and kept in their positions of authority by the European powers. The trade may have benefitted those elites, but not the majority of their countrymen.

This pattern has persisted even after most colonies had gained their freedom. Developing countries were presented with 'There Is No Alternative,' and forced to engage in highly unequal agreements, with the implicit threat of economic sanctions. They had no choice but to acquiesce to unfavorable terms.

A separate blind spot is that comparative advantage may be dynamic. Countries that now advocate, even insist on, free trade are those that those that hold comparative advantage in high value-added, often capital-intensive, sectors. These nations appear to have forgotten that they had achieved that comparative advantage by rejecting free trade and forging their own comparative advantage. (But they seem well aware that the imposition of free trade on other countries may facilitate their continuing dominance.)

If comparative advantage is dynamic, then free trade may not lead to Pareto optimal distributions. Countries forging new comparative advantages would drive competition into more value-added sectors, often requiring the protection of IPR. Potential productivity gains in these sectors tend to be larger, driving total wealth higher than it would otherwise be. History appears to bear out this claim. (Americans, in particular, might consider what their country's - and global - GDP would be if the country had remained primarily 
a producer of agricultural raw materials and had not ventured into finance, industry, technology, and the sort of innovative practices protected by IPR.)

Yet another cause of Pareto sub-optimality is short-term capital flows. Contrary to the classical picture, prices of investment vehicles - including currencies - do not fluctuate around stable equilibriums. Investors often buy a vehicle because it is appreciating, or sell it because it is depreciating. This amplifies price swings and has led to bubbles and collapses. Large swings in currency values exacerbate uncertainties surrounding long-term capital investment, especially in innovative Research and Development (R\&D). This negatively impacts economic growth, leading to long-term Pareto sub-optimal distributions.

\section{The Dubious Optimality of Pareto}

Independent of these considerations, there are serious problems with Pareto optimality itself. A slave society may well be Pareto optimal, for it may be impossible to both free the slaves and adequately recompense the owners. Moreover, there is evidence that a slave economy may be more efficient than one based on free labor (Fogel and Engerman, 1974). (This is plausible, as the threat of being killed or tortured may be an effective incentive to work harder.) One could, in principle, redistribute the products of that increased efficiency to make everyone better off. That would make free societies, less efficient than slave societies, Pareto sub-optimal.

There may be a reflection of this in the free trade issue. Even if free trade, like slavery, is more efficient, a positive-sum game, more than $100 \%$ of the gains may be captured by a few players (just as in slavery), leaving the rest with losses. The mere fact that it is possible to redistribute to make everyone better off does not guarantee that such redistribution will be undertaken, or even attempted.

These are serious problems. Any of these would nullify the advantages claimed by free trade advocates. Yet many in the economic community have refused to address, or even countenance, them (especially the consequences of a lack of autonomy, dynamic comparative advantage, and the deficiencies in Pareto optimality).

These considerations pull the free trade debate in opposite directions. At a superficial level, free trade appears to benefit all. But at a deeper level, the appearance vanishes. The longer-term dynamics of forged comparative advantage may outweigh any immediate advantages of free trade. The destabilizing effects of short-term speculative capital may make investment less attractive. And 
even if free trade were to increase total production, the deficiencies in Pareto optimality may leave most people poorer.

Practically, important trade agreements are conducted in secret, by and for powerful corporate interests. These typically seek to capture as much as they can of any benefit. Even if an agreement passes the test of increasing average productivity and total production, the capture of more than $100 \%$ of the benefits leaves the rest poorer.

It is common that one country is the overall winner, while its trading partners are impoverished. It is also common that there are a few winners and many losers in each country. This produces advocates and opponents of free trade across a spectrum, both among countries and within countries. It is typically the case that the advocates, though fewer in number, are better organized, better financed, better connected, and more keenly focused than are the opponents. And advocates find generous support in commerce, in academia, and in politics.

The separate agenda of advocates is reflected in the power of corporate funded lobbyists in the U.S. (e.g. the tobacco industry that paid lobbyists to promote without restriction their products, despite even the Federal Surgeon General warning of the deadly effects of smoking tobacco). Or in the work of academics that "helpfully" mirror the interests of corporate funders of their research (e.g. the meat industry which encourages the maximum consumption of meat, while the bulk of research by non-partisan dieticians point to gross health risks of doing this). Or politically in the U.S. President Trump's appointing to the Federal Environmental Protection Agency individuals with direct links to the coal, oil and gas industries - individuals who seek to reverse every decision made by the former Obama Administration to protect the environment. This accelerates global warming.

\section{Four Sector Losers}

In general, globalization and free trade benefit capital at the expense of labor, governments, the environment, and global socio-political health.

Labor is an immediate casualty. Work forces in countries with relatively high productivity-adjusted wages are vulnerable to having employment moved offshore. Even the threat of replacement by a global labor force functions to dampen wages, to the benefit of capital.

Governments and their citizens are negatively impacted. Corporations, encouraged to maximize after-tax profits and free to relocate to tax havens, 
have every incentive to do so. Apple Computer negotiated an income tax rate in Ireland of $0.005 \%$ and funneled a disproportionate part of its profits through dummy corporations in that country to drastically reduce its taxes (Stiglitz, 2018). Countries, deprived of corporate tax revenue, must either cut infrastructure spending (including social safety nets) or tax their private citizens more heavily.

Among other things, re-training of labor presently in unsustainable industries is not carried out. The coal industry in the U.S. is in decline while the future of energy is renewables, which employs many more than the hydrocarbon industry and in which employees need training to have a future.

The environment also suffers, as do those who depend on the environment. Compliance with environmental regulations is often expensive. Moving facilities to jurisdictions in which environmental standards are lax lowers such expenses, increasing profits. In the U.S. lobbying the Federal government (successfully) to release oil and gas producers (the source of one-third of all methane pollution) from previous policies that legislated against the release of methane accelerates climate change, but is good for the profits of hydrocarbon producers (Davenport, 2018).

Global democracy also suffers. Global trade as a fraction of economic production began a sharp increase, from about $20 \%$ in the late 1900 s to $60 \%$ today. At the same time, many nations experienced a secular change in economic disparity. That disparity had been decreasing since the end of World War II, largely as a result of political action to create and bolster social safety nets. However, as the ratio of trade to economic output increased, the fraction of benefits going to the economic elites increased.

There may be several causal patterns here. One of these is a positive feedback loop between trade primarily benefitting capital and wealth, and wealth and capital using political clout to push for more and freer trade, along with other policies that benefit capital. This has tended to concentrate wealth.

Yet extreme economic disparity is corrosive to the set of attitudes that has long been characteristic of, and may be necessary for, democracy. As a consequence, we have had the appearance of ultra-nationalist political parties in Europe, the rise to power of fascist demagogues in several countries, and the election of a would-be fascist as President of the United States (Albright, 2018).

The resentments that have fueled these extremist movements may be inchoate. But it is plausible that considerations of increasing economic disparity, exacerbated by global free trade, have played a significant causal role. That would explain the growth of fascist sentiments after World War I and today, but not after World War II. 
'During the period between the two world wars, free-market liberals governing Britain, France, and the US tried to restore the pre-World War I laissez-faire system. They put debt collection ahead of economic recovery. It was an era of rampant speculation and no controls on private capital. All this was supposed to promote prosperity and peace. Instead, it produced a decade of economic insecurity combined with heights of inequality, a discrediting of democracy, fascist backlash, and deeper depression...

As Polanyi demonstrated in his 1944 masterwork, The Great Transformation, the disembedding of markets from their societies and resulting inattention to social consequences invariably triggers a reaction. The reaction is more often chaotic and fascistic than politely democratic...' (Kuttner, 2018, p. xx).

After World War II countries tried to learn from their mistakes following World War I. And so we had the Great Compression, a period of diminished economic disparity.

This may illustrate the stakes involved and the potential severity of consequences of heading in the wrong economic direction.

One need not be wedded to any particular form of polity to appreciate the substantial evidence that countries with pluralistic political and economic institutions have succeeded while countries with extractive institutions have failed (Acemoglu and Robinson, 2012).

Given natural feedback cycles, wealth and power tend to concentrate (Piketty, 2014), leading to extractive plutocratic autocracy. Unfettered free trade would promote such concentration, wealth migrating from poorer to wealthier countries and from poorer to wealthier people within each country. Economic policies that increase economic disparity generate a risk of setting in motion processes that lead to extreme wealth concentrations, to extractive institutions, to the detriment of nations and their citizens.

\subsection{Directions Forward}

There are many economic directions in which we could head. At one extreme, we could deny (or ignore) the criticisms of free trade and proceed as though the system is the best of all possible systems in this best of all possible worlds. At the other extreme,we could retreat into autarky. In the middle, we might seek constraints on trade that would provide protection for weaker and potentially losing parties - not only countries, but individuals with weaker hands within even the stronger countries.

The first of these alternatives, though still favored by many orthodox academic economists, appears to be waning in popularity. In part, difficulties have been 
raised with standard neo-classical theory. The assumptions underlying its basic models are palpably false (e.g. behavioral economics), and its predictive track record has been poor.

Some economists, even those who reject neo-classical orthodoxy, have responded that it is possible to refine the models to generate more accurate predictions. This is surely possible. But for any desired predictions, it is possible to find some model that will generate those predictions. More important, the mode of reasoning characterized by making assumptions (models) and generating predictions as theorems is quite different from the mode of reasoning that characterizes all sciences (Friedman, 2016; 2018). Contemporary economic theory is not a theory of science.

These considerations have led some to regard the failure of neo-classical prescriptions more as failures of theory than failures of the countries at which they were directed. The diagnosis of speculative capital flows as the cause, or at least exacerbation, of the East Asian financial crisis of 1997 shed light on an important chink in the armor of neo-classical theory.

It is common that when an extreme position seems no longer dominant or tenable, it is challenged by the opposite extreme. Many American neoconservatives had converted from the opposite, Marxian, extreme. Something similar may be taking place with trade. Many people, seemingly suddenly sensitized to the loss of jobs due to imports, overlook the gain in jobs due to exports and the opportunity to re-train in expanding sectors such as renewables. No trade, or trade on unrealistically favorable terms, is seen as the solution.

Such a position may be difficult to justify economically. But politicians often lack economic sophistication, and the notion that one's country has been victimized (by others, rather than by its own economic elites) has long been an effective tool of political manipulation. Resentment based on perceived victimhood is a powerful, if dangerous, sentiment. History is littered with the outcomes of such dangerous sentiments being promulgated.

This is not to deny victimization. Rather, the perpetrators of one-sided and unfair trade agreements have been the large and politically powerful corporations that have negotiated opaque trade deals on behalf of themselves and at the expense of citizens in their own (and other) countries. While there has been victimization, the U.S., or at least its multi-national corporations and political supporters, have typically been predator, rather than prey. But they are major contributors to U.S. political parties, and it has been easy to deflect the resentment away from them.

At a national level, executives of cigarette companies long knew their product was addictive and carcinogenic. They lied to Congress about this 
and tried to make their product even more addictive (Hilts, 1996). But at an international level, '... Philip Morris... sued Uruguay in 2010 because the country passed a regulation which required the company to disclose possible harmful effects of cigarettes on health.' (Stiglitz, 2018, p. 36)

At a national level, many communities have taken steps to protect their environments, and in particular, their water supplies. But at an international level, 'When, for example, a village in the north-central Mexican state of San Luis Potosi tried to force Metalclad, a U.S. waste disposal company, to close a toxic waste site that was contaminating the local water supply, the Mexican government was forced to pay \$16.7 million in compensation, under Chapter 11 of NAFTA. Antienvironmentalists had succeeded in burying in that chapter a provision designed to halt regulation by making it too expensive... To date, suits with claims in excess of $\$ 13$ billion have been filed.' (Stiglitz, 2006, p. 130, 197)

IPR is especially important in the drugs/pharmaceutical sector. On one hand, IPR is needed by Pharma to protect its investments in R\&D to recoup its expenses. (Dewan, 2010). On the other, Pharma companies often price lifesaving medicines out of the reach of populations of poorer countries. And they have perverted IPR to 'steal' traditional medicines long used by local indigenous populations.

At a national level, if people have long been using a product, a company that had no role in the development of that product cannot acquire patent rights. But internationally, 'In the international biodiversity agreement signed in 1992 at the UN Conference on Environment and Development in Rio, the right to compensation was recognized, but, partially under the influence of the drug companies, the United States has not ratified it. And no wonder; almost half of the 4,000 plant patents granted in recent years by the United States pertain to traditional knowledge obtained from developing countries...

What the United States was asking was, we thought, not in its own interests, nor in the interests of the advancement of science, and was certainly not in the interest of developing countries. But American and European negotiators adopted the positions of the drug and entertainment industries, and others who simply wanted the strongest intellectual property rights. (A study by the Center for Public Integrity, a government watchdog group, showed that the drug industry was the single most important influence group...)

But TRIPs was designed to insure higher-priced medicines. Unfortunately, those prices made medicines unaffordable to all but the wealthiest individuals. As they signed TRIPs, the trade ministers were so pleased that they didn't notice that they were signing a death warrant for thousands of people in the poorest countries of the world.' (Stiglitz, 2006, p. 125-6, 116, 105). 
Countries have typically been able to override patents in the case of national emergencies. But internationally, 'In 1998 President Nelson Mandela signed a law that would have permitted South African drug companies to produce generic versions of AIDS drugs. The law should have been recognized by the United States as being consistent with the World Trade Organization rule that permits 'compulsory licensing' in national emergencies. But instead, Americans at all levels of government attacked the... proposal... even though Glaxo is exploiting a drug that was invented by government employees. (AZT was discovered by researchers at the Michigan Cancer Institute and Duke University, who received grants from the National Cancer Institute.)' (Adler, 2010, p. 78-9)

Hopefully, change is occurring in the US concerning the acceptance of generic drugs, which is a positive development in relation to patents and globalization. Researchers at Harvard Medical School's Program on Regulation, Therapeutics and Law (PORTAL) in conjunction with Brigham \&Women's Hospital have produced a recent study showing that generic drug companies have been successful in approximately half of their challenges of FDA-approved pharmaceutical products through a new administrative procedure of patent validity that was created by the US Congress (New, 2018).

Yet, a patent claim before the Indian High Court by UCLA in support of large Pharma companies Pfizer and Astellas shows the other side of globalization. The prostate cancer medicine was developed at UCLA but is sold through the drug companies for as much as $20 \%$ of India's median annual income. India, which has fought to promote generic drugs so successfully, may rule under pressure from UCLA to uphold the patent claim which would make it unaffordable for millions. It has been noted that UCLA is a public institution paid through US tax payers. Student activists are trying to have UCLA drop this patent claim which has the potential to deprive billions in the developing world from affordable medicines (Branigan, 2018).

These are all examples of multi-national corporations seeking to profit at the expense of developing countries. There are other features of the global free trade marketplace that exacerbate the tilt of the playing field and may extract even more from those countries than do the corporate machinations underlying specific agreements.

Free short-term capital flows, with speculation amplifying natural cycles, function to the detriment of the underlying economies. Countries must purchase expensive insurance - foreign currencies, typically the U.S. dollar - to defend their own currencies from such swings. These dollar holdings, which could otherwise be used to fund economic development, earn minimal interest rates, while the country must typically borrow at much higher interest rates to fund 
capital development. The interest rate differentials, applied to massive amounts of capital, are a boon to the U.S. financial sector, at the expense of the countries that must purchase the insurance.

In a related issue, many developing countries have enormous amounts of U.S. dollar-denominated debt. If the Federal Reserve, for purely domestic reasons, raises interest rates, the value of the dollar - and their debt - increases. This can have a destabilizing effect on the developing economies. Pegging the value of their currencies to the U.S. dollar may not be a satisfactory solution. For it is expensive, and if the U.S. dollar is strong, the peg negatively impacts the competitive position of the developing country.

These mechanisms are often taken for granted. But they have a large cumulative impact.

This does not deny that other countries, currently the Peoples Republic of China, have engaged in predatory trade tactics, from the imposition of high tariffs to government subsidies for favored sectors to outright industrial espionage. Many countries have committed these very crimes: Singapore, South Korea, Japan, Germany (in the nineteenth century), and yes, the United States. Yet we seem unaware of this history, and while we have become attuned to the predatory institutions established by the economic leaders, we are quick to take umbrage at attempts by developing countries to gain an advantage.

An awareness of this history does not address the most promising means of dealing with such issues. But it does suggest a more functional way of framing them. Developed industrialized countries have a massive inherent advantage over those trying to develop.

Successful catching-up countries have historically adopted a variety of tactics to help level the playing field. These have ranged from currency manipulation to walls of tariffs to industrial espionage. Industrial espionage itself has ranged from standard theft to hiring well-placed developed-world experts in technology, from de- and re-engineering to demanding technology and sole rights to patents of jointly developed products in return for access to large consumer markets.

\section{Conclusions}

Can one draw a cogent distinction between those policies that may be regarded as legitimate and those that are clearly illegitimate? Independently, are there programs or partnerships, perhaps involving technology sharing, that more advanced countries could offer that would spur economic growth 
in both themselves and the developing countries? (The Republic of Korea or South Korea as commonly known has pursued just such policies between large European technology companies and innovative ROK companies being developed in their science parks, see for examples Taplin, 2018). Are there ways of stimulating additional economic growth that would benefit most people? If single countries could not capture enough of the benefits to justify their investments, could multi-national institutions provide catalysis, triggering a feedback loop in which the increased economic growth of countries has a positive effect on the growth of neighboring countries?

This sort of question may be appropriate for those seeking a middle path, trade that is reasonably regulated. This may be the wisest path, though it is the most complex and difficult.

One issue it implicitly raises is the limits of trade policy. As one example, should trade agreements include tax provisions? Should they be impediments to corporations seeking to minimize their taxes by artificially locating profits in tax havens? (One could tax multi-national corporations at the venues of final sales to consumers and at the prevailing tax rates of the countries in which the products or services are sold. This would, for example, make the income tax of an aircraft producer independent of the domicile of either itself or of the purchasing airline. In effect, countries would demand that those corporations that profit from selling them goods and services pay income taxes to them. One could institute similar taxes on investments.) That would protect governments (and citizens) from being deprived of corporate tax revenue.

Trade agreements could also protect the environment, by regarding lax environmental standards as providing an unfair advantage to producers, an advantage that may be legitimately countered by tariffs.

In a similar vein, it may be possible to insist on minimal standards for labor, regarding a violation of those standards as providing an unfair advantage that may be countered by tariffs.

Some consumer protection may be provided by demands of transparency, that countries have the right, and perhaps the duty, to test products and to publicize potential adverse safety data.

These considerations may provide minimal protections. Attention to form may yield additional substantive protections. In particular, it may be reasonable to demand not only transparency, but also meaningful representation by advocates for those who would be most likely shortchanged: labor, the environment, government, consumers. 


\section{References}

Acemoglu, D. and Robinson, J. (2012). Why Nations Fail: The Origins of Power, Prosperity, Poverty. New York: Crown Business.

Albright, M. (2018). Fascism: A Warning. New York: Harper Collins.

Branigan, D. (2018). Student Activists Swarm To Demand UCLA Drop Indian High Court Patent Claim. Intellectual Property Watch online, 6 September.

Cohen, S. and DeLong, J.B. (2016). Concrete Economics: The Hamilton Approach to Economic Growth and Policy. Cambridge: Harvard Business Review Press.

Davenport, C. (2018). Trump Administration Wants To Make It Easier To Release Methane Into The Air. New York Times, 10 September.

Dewan, M. (2010). Socio-economic changes effected by intellectual property rights: the Indian perspective. In: R. Taplin, A. Z. Nowak (Eds), Intellectual Property, Innovation and Management in Emerging Economies. Oxon: Routledge.

Fogel, R. and Engerman, S. (1974). Time on the Cross: The Economics of American Negro Slavery. New York: W. W. Norton and Company.

Friedman, K. (2016). Econoclastics 201: Meta-economics - Is Economics a Science? Interdisciplinary Journal of Economics and Business Law, 5(3), 76-101.

Friedman, K. (2018). Structural Failures and Non-structural Defects of Economic Theory. Interdisciplinary Journal of Economics and Business Law, 7(3).

Kuttner, R. (2018). Can Democracy Survive Global Capitalism? New York: W. W. Norton and Company.

New, W. (2018). Study: Generic Drug Industry Embraces Faster, Cheaper Pathway For Challenging Patents. Intellectual Property Watch online, 6 September.

Nixon, R. (2018). Smuggling of US Technology Outpacing Cold War Levels Experts Say. New York Times, 17 March.

Piketty, T. (2014). Capital in the Twenty-first Century. Cambridge: Harvard University Press.

Rodrik, D. (2011). The Globalization Paradox: Democracy and the Future of the World Economy. New York: W. W. Norton and Company.

Rodrik, D. (2017). Straight Talk on Trade: Ideas for a Sane World Economy. Princeton: Princeton University Press.

Stiglitz, J. (2006). Making Globalization Work. New York: W. W. Norton and Company.

Stiglitz, J. (2017). Globalization and Its Discontents Revisited: Anti-Globalization in the Era of Trump. New York: W. W. Norton and Company.

Taplin, R. (2016). Postscript. In: R. Taplin (Ed), Managing Cyber Risk in the Financial Sector: Lessons from Asia, Europe and the USA. Oxon: Routledge.

Taplin, R. (2018). Innovation, Investment and Intellectual Property in South Korea: Park to Park, Oxon: Routledge. 